DOI 10.37882/2223-2982.2020.06-2.26

\title{
ЛЕКСИКО-СЕМАНТИЧЕСКИЕ ПАРАЛЛЕЛИ В АЛТАЙСКОМ И КИРГИЗСКОМ ЯЗЫКАХ (НА МАТЕРИАЛЕ МЕНТАЛЬНЫХ ГЛАГОЛОВ)
}

\section{LEXICAL-SEMANTIC PARALLELS IN ALTAI AND KYRGYZ LANGUAGES (ON THE BASE OF MENTAL VERBS)}

\section{B. Sanalova}

Summary: Lexical parallels are the object of research where we can find out both common and quotient in compared languages. In this article lexical-semantic characteristics of Altai Kyrgyz parallels are viewed on the example of lexical-semantic groups of verbs denoting mental processes.

Keywords: Altai language, Kyrgyz language, verb, meaning, semantics, lexical-semantic variant.

\author{
Саналова Байару Борисовна \\ К.филол.н., С.н.С., НИИ алтаистики им. С.С. Суразакова \\ (Горно-Алтайск) \\ sbayaru@mail.ru
}

Аннотация: Лексические параллели являются тем объектом исследования, при изучении которого можно выявить как общее, так и частное в сопоставляемых языках. В данной статье рассматриваются лексико-семантические особенности алтайско-киргизских параллелей на примере лексико-семантической группы глаголов мыслительной деятельности.

Ключевые слова: алтайский язык, киргизский язык, глагол, значение, семантика, лексико-семантический вариант.
Д ля выявления общих системных свойств лексики разных языков и специфики каждой из них очень многое дает применение сопоставительно-конвной методики. Сопоставительный метод «исследование и описание языка через его системное сравнение с другим языком с целью прояснения его специфичности. Сопоставительный метод направлен в первую очередь на выявление различий между двумя сравниваемыми языками и поэтому называется также котрастивным» [5].

Сопоставление лексических единиц различных языков, как и единиц других уровней, необходимо для разрешения различных проблем методики преподавания языков, лексикографии, теории и практики перевода. Ученые считают, что единой базой для сопоставления лексики может послужить направленность лексических единиц на одну и ту же экстралингвистическую реальность, одинаковую для всех людей, независимо от их родного языка [2, с. 5; 4, с. 4], и материалом исследования должны послужить определенные ЛСГ. В данном исследовании это ЛСГ мыслительной деятельности.

Сопоставительный метод особенно эффективен применительно к родственным языкам, так как их контрастные черты проступают наиболее ярко на фоне сходных черт. В нашей работе объектом сопоставления явились родственные алтайский и киргизский языки. Близость этих языков определяется этногенетической и историко-культурной связью алтайского и киргизского народов. По классификации Н.А. Баскакова алтайский и киргизский язык вместе составляют киргизско-кыпчакскую группу восточнохуннской ветви тюркских языков [1].

Как было отмечено выше, при сопоставлении двух языков выявляются общие (универсальные) и частные (специфические) черты, присущие данным языкам. В этой связи лексические параллели являются тем объектом исследования, при изучении которого можно выявить как общее, так и частное в рассматриваемых языкax.

В данной статье нами предпринимается попытка выявить лексико-семантические особенности алтайско-киргизских параллелей на примере лексико-семантической группы глаголов мыслительной деятельности. Наша цель - выявить некоторые сходные черты, а также указать на ряд расхождений в семантической структуре алтайских и киргизских слов. Под «лексическими параллелями» в статье, вслед за В.В. Дубичинским, мы понимаем «Совпадающие в плане выражения, сходные / несходные в плане содержания лексемы двух и более синхронически сравниваемых или контактирующих языков» [3].

Для анализа сопоставления мы берем в алтайском языке данные, полученные в результате нашего исследования, и в киргизском языке данные «Киргизско-русского словаря» [1957] (далее КРС) под редакцией К. К. Юдахина и данные, полученные от информантов, носителей киргизского языка.

Нами рассматриваются следующие алтайско-киргизские лексические параллели: алт. бил= 'знать'- кирг. бил= 'знать'; алт. 
вать'; алт. кӧр= 'смотреть, видеть' - кирг. көр= 'смотреть, видеть'; алт. сес= 'чувствовать' - кирг. сез= 'чувствовать'; алт. $\ddot{р е н=' ~ ' у ч и т ь, ~ у ч и т ь с я ' ~-~ к и р г . ~ ү и ̆ р ө н=' у ч и т ь ' . ~}$

Глагол бил='знать' имеется в большинстве современных тюркских языков. В алтайском языке система значений глагола бил= представлена пятнадцатью ЛСВ:

ЛСв ${ }_{1}$ 'хранить в сознании информацию о чем-л., иметь сведения о чем / ком-л.';

лсв ${ }_{2}$ 'обладать знанием чего-л., иметь специальные познания в какой-л. области (свое дело, язык и т.д.)':

а) 'уметь что-л. делать';

б) 'не уметь что-л. делать';

лсв ${ }_{3}$ 'быть знакомым с кем-л.:

а) 'узнавать, отличать от других';

б) 'ориентироваться где-н.;

лСв 'понимать, сознавать, отдавать себе отчет в чем-л.';

ЛСв ${ }_{5}$ 'догадаться, сообразить, напасть на правильную мысль';

лСв 'замечать';

лсв ${ }_{7}$ 'соблюдать, считаться с чем-л.';

лсв ${ }_{8}$ 'иметь мнение';

ЛСв , 'обдумав, прийти к какому-л. решению, необходимости каких-н. действий';

лСв ${ }_{10}$ 'испытать, переживать';

ЛСВ ${ }_{11}$ 'управлять, распоряжаться';

лСв $_{12}$ выступает определением к слову кижи 'человек' в значении 'ясновидящий (человек)';

ЛСВ ${ }_{13}$ грам. в значении вводного слова;

ЛСВ ${ }_{14}$ грам. в значении служебного слова;

ЛСВ $_{15}$ грам. в значении вводного слова.

Для киргизского глагола бил= 'знать' КРС выделяет лишь три значения:

ЛСВ ${ }_{1}$ Знать, понимать';

ЛСВ ${ }_{2}$ 'мочь, быть в состоянии';

лСв ${ }_{3}$ 'управлять, распоряжаться'.

По данным же информантов, семантическая структура данного глагола более шире.

КРС в словарной статье глагола бил= под номером один располагает два значения: 'знать' и 'понимать'. Мы же считаем неправильным рассматривать эти два значения в одном ряду. В содержании киргизского глагола бил=, как и во всех тюркских языках, в которых представлен такой глагол, ядром, основным семантическим компонентом, выступает компонент «знание», но не компонент «понимание».

Так что, в качестве основного значения для киргизского слова бил= мы считаем целесообразным выносить значение 'знать' и определяем его как 'хранить в сознании информацию о чем-л., иметь сведения о чем / ком-л.' В отличие от алтайского глагола бил=, реализующего данное значение при объекте предикативного типа в форме винительного падежа, со служебным словом деn, а также в конструкции с послелогом керегинде 'о', киргизский глагол бил= ограничивает реализацию лишь формой винительного падежа при предикативном типе объекта. Например: кирг. Чын-төгүнин ким билсин, элдин жомогунда караганда дүйнөдө бир мастан кемпир болгон экен (ГКЯ: 283) 'Правда или нет, кто знает, но в народных сказках говорится, что жила на свете баба-яга'.

Вторым значением для киргизского глагола бил= вполне можно выделить характерное и для алтайского глагола бил= значение 'обладать знанием чего-л., иметь специальные познания в какой-л. области'. Подтверждением этого значения служат следующие примеры: кирг. Мен немец тилин билем (Р) 'Я знаю немецкий язык (понимаю и говорю)'; кирг. Мен оз ишим билем (Р) 'Я знаю свое дело'.

Значение 'мочь, быть в состоянии', выделяемое для киргизского слова в КРС, мы рассматриваем как образованное на базе предыдущего значения, т. е. значения 'обладать знанием чего-л., иметь специальные познания в какой-л. области'.

В алтайском языке значение 'мочь, быть в состоянии' распределяется по двум оттенкам: а) 'уметь что-л. делать' и б) 'не уметь что-л. делать', формирующийся отрицательной формой глагола бил= - бил=бе. Последний оттенок значения является «обусловленным тематическим типовым контекстом», когда отмечается указание на связь слова с каким-то кругом явлений действительности (с состоянием человека, с его эмоциональной или мыслительной деятельностью) и соответствующим тематическим классом слов. В данном случае таким «тематическим классом слов» являются слова, обозначающие духовные качества человека: aлm. Уйаларын билбес кижи'Человек, который не умеет стыдиться'; aлm. Ол ачынып билбес јанду кижи 'Он не обидчивый человек (букв.: с не умеющим обижаться характером)'. Рассмотренный оттенок значения является специфичным для алтайского глагола бил=. Это говорит о том, что слова разных языков, имея сходную семантику, могут быть глубоко национальными, неповторимыми.

Значение 'мочь, быть в состоянии' киргизского глагола бил= получает реализацию следующим образом: в сочетании глагола бил= с причастием на =ган в винительном падеже; причем, форма винительного падежа факультативна. Например: $\mathbf{a л m . ~ М е н ~ т ү ү и ̆ = г е н ( \partial ү ) ~ б и - ~}$ лем (Р) 'Я умею вязать'; кирг. Мен машина айда=ган(ды) билем (Р) 'Я умею водить машину'. В алтайском языке подобное значение выражается в сочетании глагола бил=с деепричастием на =n. Например: Мен крючокло тӥ̈̈н= $\underline{\text { un }}$ билерим 'Я умею вязать крючком'.

Следующее значение 'быть знакомым с кем-л.' с по- 
следующими от него оттенками выявляется в семантических структурах обоих сопоставляемых глаголов. Например:

алm. Аринанын сыйындарын мен билерим 'Я знаю младших сестер Арины';

кирг. Мен аның эжезин билем (Р) ‘Я знаю его сестру'.

В рамках рассмотренного значения в обоих языках одинаково выявляются следующие оттенки:

а) 'узнавать, отличать от других':

алт. Мен сенин тонынды билерим, эмди экелип берерим (И) 'Я знаю твое пальто, сейчас принесу';

кирг. Мен аның жазуусун билем (Р) 'Я знаю его почерк'.

Данное значение параллельно с глаголами бил= в алтайском и киргизском языках передают глаголы таны= в алт. и тааны= в кирг. Например:

алт. Ол мени эмди таныбас болуп калган (И) ‘Он теперь стал не узнавать меня';

кирг. Мен аның иттин тааныйм (Р) 'Я узнаю его собаку';

б) 'ориентироваться где-н'.:

aлm. Бу ороомды мен ӱзезинен јакшы билерим (И) 'Эту улицу я лучше всех знаю (лучше всех ориентируюсь)';

кирг. Мен шаарды билем, ошондуктан мен слерди зоопаркка апарам (Р) ‘Я знаю город, поэтому я отведу вас в зоопарк'.

Алтайский глагол таны='узнавать' и киргизский таaны= 'узнавать' являются лексико-семантическими параллелями при небольшом отличии в плане выражения.

В киргизском языке, как и в алтайском, нет специального слова, за которым закреплено значение 'догадываться.' В алтайском языке это значение передает ряд глаголов: сес= 'чувствовать', бил= 'знать', ондо= 'понимать', аайла= 'понимать'; в киргизском языке значение 'догадываться', согласно информантам, выражается глаголами бил= 'знать' и сез= 'чувствовать'.

КРС в словарной статье глагола бил= 'знать', в отличие от глагола сез= 'чувствовать', не выделяет значение 'догадываться', но выделяет значение 'понимать'. Информанты, носители киргизского языка, не разграничивают эти два значения, давая при переводе одного и того же предложения с глаголом бил= с киргизского на русский язык и глагол понимать, и глагол догадываться. Например:

кирг. Мениц келишим ага жакпай калганын билдим (Р) 'Я догадался (понял), что он не рад моему приходу';

кирг. Мен аның алдап жатканын билип жатам (Р) 'Я понял (догадался), что он обманывает'.

Следует отметить, что в алтайском языке значения 'понимать' и 'догадываться' также не имеют специальных отличительных внешних признаков. Носитель алтайского языка в переводе фразы с глаголом бил= с алтайского на русский язык может использовать одинаково и глагол понимать, и глагол догадываться. Здесь следует говорить о взаимопроницаемости этих двух значений глаголов бил= в обоих сопоставляемых языках, то есть своего рода нейтрализации присущих им (значениям) особых дифференциальных признаков. В семантической структуре алтайского глагола бил= рассматриваемые два значения ('понимать' и 'догадываться') мы выносим как два отдельные самостоятельные значения с общим для них семантическим компонентом «понимание». Это же можно сказать относительно семантической структуры киргизского глагола бил=.

Различие наблюдается в объектной направленности глаголов бил= алтайского и киргизского языков. Объектом понимания при алтайском глаголе бил= может быть некоторое лицо:

алт. Мен сени билип јадым, сеге кандый кӥчтерди ӧдӧргё келиишкен (И) 'Я тебя понимаю, какие трудности тебе пришлось испытать' При киргизском глаголе бил= в позиции объекта понимания использование некоторого лица невозможно.

Значение 'замечать' возникает у алтайского глагола бил= в отрицательной форме и в сопровождении с усилительной частицей да. Например:

алт. Кыштын ӧткӧнин билбей де калдым (И) 'Я и не заметил, как прошла зима'. Киргизский глагол бил=, формируя это значение так же в отрицательной форме, в отличие от алтайского глагола не требует при себе усилительной частицы:

кирг. Мен үйге келип калганымыды билбей калдым (Р) 'Я и не заметил, как дошел до дома';

кирг. Мений отпускум бүткөнүн билбей калдым (Р) ‘Я не заметил, как прошел мой отпуск'.

Далее полный параллелизм наблюдается по следующим трем значениям: 'соблюдать, считаться с чем-н.' Например:

алт. Курсакта кемин бил 'Знай меру в еде'; кирг. Ар бир киши бардык нерселердиң ченин билиш керек (Р) 'Каждый должен во всем знать меру'.

Значение 'обдумав, прийти к какому-н. решению, к необходимости каких-л. действий' в обоих языках одинаково возникает в форме повелительного наклонения:

алm. Ол ишке кирерин бе, јок по бойын бил (И) 'Сам решай, будешь ты устраиваться на эту работу или нет';

кирг. Мындан ары эм не кыларыңды өзүң, бил (Р) 'Дальше сам решай, что будешь делать';

кирг. Үйге кетериңди өзүң бил (Р) 'Сам решай, когда поедешь домой'.

Значение 'управлять, распоряжаться', которое мы выделяем для алтайского глагола бил= и находим его (значение) в словарной статье киргизского глагола бил= в KPC, мы рассматриваем как генерализованное значение, 
при котором происходит расширение денотата. В данном случае объект, на который направлен глагол бил= в алтайском языке и киргизском языках, объединяет в себе обозначение всех действий, каким-то образом связанных с ним. Например:

алm. Тойдын аракыларын акам билер (И) 'Спиртными напитками, купленными на свадьбу, распоряжается старший брат (знает когда и что ставить, кому ставить; букв.: брат знает спиртные напитки)';

кирг. Биздин үй-бүлөдө акчаны эжем билет (Р) 'У нас в семье деньгами распоряжается мама'.

Систему значений обоих сопоставляемых глаголов дополняют их грамматикализованные значения. Для алтайского глагола как грамматикализованные значения рассматриваются:

1) употребление в функции вводного слова с целью обратить внимание собеседника на предмет разговора (в сопровождении с вопросительной частицей и в начале предложения): Билерин бе, мен бӥгїн магазинде ондый јараш сыргалар кӧргӧм (И) 'Знаешь, я сегодня в магазине такие красивые серьги видела';

2) употребление в качестве служебного слова с семантикой утверждения правдивости чего-л. (в сопровождении с вопросительной частицей и в конце предложения): Мен оны сеге качан да айтпазым, билдин бе'Этого я тебе никогда не скажу, понял';

3) употребление в функции вводного слова с целью убедить собеседника в важности сообщаемой информации; в данном случае бил= имеет форму условного наклонения: Билзен, ол кижи ондый јаан иш бӥдӥрген (И) 'Пойми, этот человек выполнил такую большую работу'.

Последнее грамматическое значение алтайского глагола бил= характерно и для аналогичного киргизского глагола; киргизский глагол реализует его так же в форме условного наклонения:

кирг. Ал, билсең, бизге абдан жардым кылды (КРС) 'Он, понимаешь ли, очень помог нам'.

Таким образом, при сравнении семантических структур глаголов бил= 'знать' в алтайском и киргизском языках мы выяснили, что значения алтайского глагола бил= покрывают все выделенные значения киргизского глагола бил=. Алтайский глагол бил= имеет пятнадцать значений, и из них десять значений обнаружено и у киргизского глагола. Остальные пять значений алтайского глагола бил=, не обнаруженные в семантической структуре киргизского глагола, специфичны для алтайского слова.

В алтайском языке в ЛСГ глаголов мыслительной деятельности входят два глагола, основные значения которых позволяют рассматривать их в составе других ЛСГ. Вхождение их в ЛСГ мыслительной деятельности связано с обнаружением в их семантических структурах производных значений с интеллектуальным уклоном.
Это основной глагол зрительного восприятия кӧр= 'смотреть, видеть' и сес= с основным значением 'чувствовать'.

Глагол кӧр= 'смотреть, видеть' представлен во всех современных тюркских языках. В алтайском языке для глагола кӧр= мы выделяем семь значений, которые позволяют рассматривать его в рамках ЛСГ мыслительной деятельности:

ЛСв ${ }_{1}$ 'сознавать, понимать';

ЛСв ${ }_{2}$ 'проверять, удостовериться в правильности чего-н., обследовать с целью контроля';

лСв ${ }_{3}$ 'подвергнуть испытанию для выяснения чего-н.'; лСв ${ }_{4}$ 'обследовать, осмотреть (врачебное дело)';

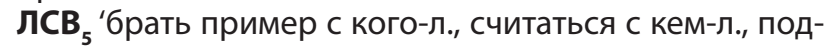
ражать';

лсв 'переживать, испытывать';

ЛСВ ${ }_{7}$ 'иметь мнение, точку зрения на что-н., расценивать как-н.'

В семантической структуре киргизского глагола көр= 'смотреть, видеть', согласно данным КРС, мы находим три значения с интеллектуальным уклоном. С алтайским глаголом кӧр= киргизский көр= пересекается в значении 'переживать, испытывать'. В обоих языках данное значение представлено как расширенное генерализованное; глаголы кӧр=и көр= в данном значении обозначают восприятие жизни вообще. Например:

aлm. Карганак јӱрӥминде нени кӧрбӧди деер (И) 'Чего только не испытал старик в своей жизни';

кирг. Көрбөгөнду калбаган (КРС) 'Он все испытал; нет ничего, чего бы он не испытал'; Жылкычы бир көргөнүн хан, бир көргөнүн ит көрбөйт (КРС) 'То, что испытывает табунщик, часом хан, часом пес испытывает (о раздолье на летних пастбищах и зимних муках табунщика)'.

Семантический компонент «испытание» представлен в качественно ином оттенке в значении 'подвергнуть испытанию для выяснения чего-л.' алтайского глагола кӧр=. Например: Машинаны кӧр= 'Испытать машину (проверить состояние)'.

В значениях 'считать чем-л., принимать за что или за кого-л.' киргизского глагола көр= и 'иметь мнение, точку зрения на что-н., расценивать как-н.' алтайского глагола кӧр= обнаруживаются общие для них семантические признаки «мнение и оценка». Отсюда вытекают характерные для обоих языков словосочетания:

aлm. ас кӧр / кирг. аз көр='считать недостаточным, находить что мало' и с антонимичным значением алm. кӧn кӧр = / кирг. көп көр= 'принимать за многое, считать, что много'. В следующих примерах четко отражены одновременно семантические компоненты «мнение и оценка»:

кирг. Атымды ат көрбөйт (КРС) 'Он мою лошадь лошадью не считает (оценивает лошадь отрицательно)';

алт. Бу аттарды јёдек кӧрбӧгӧр 'Не считайте этих коней слабыми (плохими)'. 
На основе выше рассмотренных словосочетаний типа ас кӧр, көп көр возникли более лексикализованные словосочетания типа алт. јакшы кӧр / кирг. жакшы көр 'любить, симпатизировать' и алт. јаман кӧр / кирг. жаман көр 'ненавидеть, относиться пренебрежительно'. Из этого следует семантическая многофункциональность глаголов кӧр = и көр=, то есть они могут входить также и в ЛСГ глаголов чувства.

На базе выше рассмотренного значения 'считать чем-л., принимать за что или за кого-л.' киргизского глагола көр= образовано следующее его значение 'считать кого-л. виновником, причиной чего-л.' Это значение специфично для киргизского глагола көр=, оно не выявляется в семантической структуре алтайского глагола $к \ddot{p}=$. Реализуется это значение в сочетании глагола көр= с объектом в исходном падеже:

кирг. Сен=ден көрдүм (КРС) 'Я тебя считаю виноватым (тебя подозреваю)'; Жаман катын терисин жыйбай,

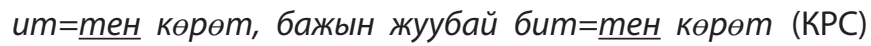
'Дурная женщина шкуру не убирает, да собаку винит, голову не моет, да вшей винит'.

Информанты, носители киргизского языка, подтвердили наличие в семантической структуре киргизского глагола көр= 'смотреть, видеть' еще трех выявленных нами значений, которые имеют место и в семантической структуре алтайского глагола кӧр='смотреть, видеть'. Эти значения: 'обследовать, осмотреть (врачебное дело)'. Киргизский глагол көр=, как и соответствующий алтайский эквивалент, реализует данное значение в своем переходном употреблении: Бүгүн бизди шаардон келген дарыгерлер көрду (Р) 'Сегодня нас осматривали врачи, приехавшие из города'. Значение 'брать пример с кого-л., считаться с кем-л., подражать', выявляемое параллельно в семантических структурах обоих сопоставляемых глаголов, реализуется в их сочетании с объектом в винительном падеже. Например:

кирг. Агасы프 көруп, иниси өзөт - алт. Аказы프 кӧрёп, карындажы ӧзӧт 'Глядя на старшего брата (беря пример с брата), и младший брат подрастает'. Значение 'проверять, удостовериться в правильности чего-л., обследовать с целью надзора, контроля' алтайский глагол кӧр= формирует по отношению к разным типам объектов: традьтар кӧр'проверять тетради'; тракторды кӧр'проверять трактор (например, не нужен ли ремонт)', также в качестве объекта может выступать целая предикативная единица. Киргизский же глагол көр= реализует данное значение только в сочетании с объектом предикативного типа. В обоих языках при объекте предикативного типа позиция связки деп является факультативной. Примеры:

кирг. Буюндорду ордунда бекен (деп) көруш керек алт. Ончо неме јеринде бе (деn) кӧрӧр керек 'Нужно проверить все ли на месте'.
Таким образом, сопоставив глаголы кӧр= и көр=алтайского и киргизского языков, мы убедились в семантической многофункциональности этих глаголов. Будучи основными глаголами зрительного восприятия в соответствующих языках, они входят в ЛСГ мыслительной деятельности, а также являются составными компонентами лексикализованных словосочетаний, значения которых позволяют рассматривать их в ЛСГ глаголов чувства.

Второй глагол, входящий в ЛСг мыслительной деятельности в алтайском языке по производным значениям интеллектуального смысла, это глагол сес=.

Согласно А.А. Юлдашеву, глагол сес= соответствует монг. sere 'бодрствовать', 'чувствовать', фин. herata 'просыпаться', тунг. seri 'будить', serm, seriv 'просыпаться' [7, с. 296].

Во всех тюркских языках, в которых представлен глагол сес=, основным значением последнего является обозначение восприятия, являющегося результатом воздействия чего-л. или кого-л. на органы чувств, исключая зрение и слух. Так что, глагол $c е c=$ обозначает самое широкое понятие чувственного восприятия, под которое подходят и значения 'ощущать', 'чувствовать,' 'осязать'.

Поскольку характер восприятия в каждом конкретном случае так или иначе уточняется посредством контекста или сочетающимся с данным глаголом словом (например: aлm. соок сес 'чувствовать холод'; јыт сес 'чувствовать запах'), тюркские языки не ощущают необходимости обозначать такие разновидности чувственного восприятия, как осязать, ощущать, чувствовать и т. п. отдельными словами. Итак, глаголу сес= в тюркских языках присуще основное значение, покрывающее собой, по существу, все указанные русские соответствия (ощутить, чувствовать, осязать).

В алтайском языке этот глагол представлен как сес=, в киргизском языке ему соответствует вариант с озвончением в конце - сез=. В киргизском языке наряду с сез= употребляется для обозначения чувственного восприятия глагол туй=, который, как отмечает А.А. Юлдашев, встречается также в узбекском, кара-калпакском, казахском, чувашском, татарском и, в отличие от сез=, обозначает понятие «чувствовать» в его наиболее отвлеченном виде [7, с. 298].

Вхождение алтайского глагола сес= в ЛСГ мыслительной деятельности связано с явлением транссемантизации, т.е. «переходом одной семемы в другую путем изменения признаков» $(6$, с. 7). В данном случае оказывается измененным характер ощущения, а именно ощущение, связанное с чутьем, интуицией. Это следующие значения:

лСв ${ }_{1}$ 'распознавать чутьем, интуитивно чувствовать, предполагать, чуять'; 
лсв ${ }_{2}$ 'иметь предчувствие чего-н. (назревающего, предстоящего или неизвестного)';

ЛСВ ${ }_{3}$ 'достигнуть понимания чего-л., понять';

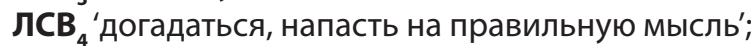

лсв ${ }_{5}$ 'замечать'.

КРС выделяет для киргизского глагола сез= 'чувствовать' лишь два интеллектуальных значения. Эти значения: 'чувствовать, распознавать чутьем'; 'догадаться'. Однако, данные, полученные от информантов, носителей киргизского языка, свидетельствуют о полном параллелизме семантических структур киргизского глагола сез= и алтайского глагола сес=. Таким образом, семантическая структура киргизского слова сез=, как и алтайского сес=, включает в себя пять интеллектуальных значений:

лСв ${ }_{1}$ 'распознавать чутьем, предполагать, чувствовать интуитивно, чуять': Сен сүүп калганыңды сезип атам (Р) ‘Я чувствую, ты влюбился'; Сен алдап жатканыңды мен сезип жатам (Р) 'Я чувствую, что ты лжешь';

ЛСв $\mathbf{2}_{2}$ 'иметь предчувствие чего-н. (назревающего, предстоящего или неизвестного)': Экзаменди табыштыралбай каларымды сезип атам (Р) ‘Я чувствую, что не сдам экзамен'; Эртен коноктор келерин мен сезип жаmaм (Р) 'Я чувствую, что завтра у нас будут гости';

ЛСВ ${ }_{3}$ 'достигнуть понимания чего-н., понять': Лиданы сүҮйгөнҮн аның айтыми бойынча сездим (Р) 'То, что он неравнодушен к Лиде, я понял по его рассказу';

лСв ${ }_{4}$ 'догадаться, напасть на правильную мысль': Маратты бис алдаватканыбызды ал сезди (Р4) 'Марат догадался, что мы его разыграли'; Курдамымның келгенин мен сездим (Р) 'Я догадался, что ко мне приехал друг';

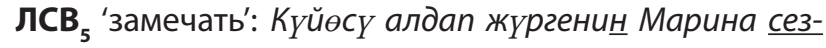
бей жүрөт (P) Марина не замечает, что муж ее обманывает'; Жазгуль суунун ар көзүндө кандай мал турганын сезди (Р) 'Жазгуль догадалась, какой зверь был на том берегу реки'.

Итак, мы выяснили, что сравниваемые глаголы сес= и сез= не только совпадают в плане выражения при небольшом отличии (использование конечного глухого согласного $=c=$ в алтайском языке обусловлено языковыми нормами, не допускающими использование звонких согласных в конце слова), но и полную эквивалентность смысловых структур этих глаголов. Отличие имеет место В условиях реализации значений: для киргизского глагола сез= универсальной формой, в которой одинаково реализуются все его значения, является форма винительного падежа при предикативном типе объекта; алтайский глагол для реализации своих значений использует форму неопределенного и винительного падежей при предикативном типе объекта, а также предикативный тип объекта со служебным словом деn.

Алтайский язык для обозначения мыслительной деятельности человека, направленную на приобретение каких-л. знаний, использует глагол ӥрен=. Семантиче- ский компонент «приобретение знаний» пронизывает всю его семантическую структуру, которая представлена пятью значениями:

лСв 1 'усваивать, приобретать какие-л. знания, умения, навыки';

ЛСв ${ }_{2}$ 'занимаясь, усваивать, запоминать';

лСв ${ }_{3}{ }^{\prime}$ постичь учением, усвоить в процессе обучения;

лСв ${ }_{4}$ 'получать образование, специальность';

лсв ${ }_{5}$ 'подражая, усвоить, перенять, брать пример'.

Алтайский глагол ӥрен= объединяет в себе значения, распределенные в киргизском языке по двум словам Yйрөн= и оку=: где алтайский язык обходится одной единицей, киргизский язык использует две. В данном случае нас будет интересовать только глагол үйрөн=, являющийся лексико-семантической параллелью алтайского глагола ӱрен=.

Итак, значение 'усваивать, приобретать какие-л. знания, навыки, умения', характерное для алтайского глагола $\ddot{р е н=, ~ в ~ к и р г и з с к о м ~ я з ы к е ~ с в о и ̆ с т в е н н о ~ г л а г о л у ~}$ үйрөн=. Алтайский глагол ӱрен= реализует данное значение следующим образом:

а) в сочетании с инфинитивом: кычыр=арга $\ddot{\text { урен }}$ 'учиться читать';

б) в сочетании с деепричастием на $=n$ : шахмат ойно= $\underline{n} \ddot{y} е н^{\prime}$ 'учиться играть в шахматы';

в) в сочетании с отглагольными именами существи-

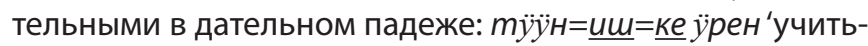
ся вязанию'.

Киргизский глагол үйрөн= в отличие от алтайского глагола ограничивает реализацию значения лишь одним способом, а именно в сочетании с причастием на =ган в винительном или дательном падеже. Например:

Мен гитараны ойно $=2 \mathrm{OH}=20 / \partial y$ үйрөнүп жатам (Р) ‘Я учусь играть на гитаре'; Мен трактор айдо $=20 \mathrm{H}=20 / \partial y$ Үйрөндүм (KPC) ‘Я научился управлять трактором'.

Значение 'постичь учением, усвоить в процессе обучения' характеризуется семантическим признаком «протяженность во времени». Для выражения этого значения киргизский язык использует как глагол оку=, так и глагол Үйрөн=; причем, носители киргизского языка не видят никакой разницы в употреблении этих глаголов в данном значении. Например:

Тилдин тарыхын үйрөн (КРС) 'Изучать историю языка'; Биз биринчи курста университетте английск тилин окугонбиз (Р) 'В университете на первом курсе мы изучали английский язык'.

Кроме того, в семантических структурах обоих сопоставляемых глаголов имеет место значение 'подражая, усвоить, перенять, брать пример', Оба сопоставляемых языка для реализации данного значения используют сочетание соответствующих глаголов с объектом в ис- 
ходном падеже; причем, позицию объекта занимает некоторое лицо, являющееся источником какого-то знания (примером подражания). Например:

aлm. Эјелер $=\underline{\partial е н} \ddot{y р е н}{ }^{\prime}$ Учиться у сестер (брать пример с сестер)';

кирг. Мен дайыма энем= $\underline{\partial е н}$ үйрөнөм (Р) ‘Я всегда беру пример с моей мамы'. Кроме того, в алтайском языке маркером реализации рассматриваемого значения выступает имя существительное в дательном падеже, служащее названием какого-то знания. Например:

алт. Cама нӧкӧринин каткызы=на ӱренип алган 'Саша перенял от своего друга его смех'.

Таким образом, мы выяснили, что алтайский глагол $\ddot{y р е н=~ с о ~ з н а ч е н и е м ~ ' у ч и т ь, ~ у ч и т ь с я ' ~ и м е е т ~ э к в и в а л е н т а-~}$ ми в киргизском языке два глагола үйрөн= и оку=. Если алтайский глагол имеет в своей семантической структуре пять значений, то киргизскому глаголу үйрөн= свойственны два из них, два значения - глаголу оку=; лишь в одном значении эти два глагола пересекаются.

\section{Список условных сокрашений}

ГКЯ - Грамматика киргизского языка. - Фрунзе, 1987.

И - Информант (носитель алтайского языка).

КРС - Киргизско-русский словарь. Под ред. К.К. Юдахина. - М., 1965.

P - Информант (носитель киргизского языка).

ЛИТЕРАТУРА

1. Баскаков Н.А. Алтайский язык. - М., 1958.

2. Гинзбург Е.Л. 0 двух уровнях семантического анализа //Actes du X Gongres Internatjonal des Lunguistes. - Bucarest, 1970. - C. 5.

3. Дубичинский. В.В. Теоретическое и лексикографическое описание лексических параллелей : дис. ... д-ра филол. наук. Краснодар, 1995. 311 с.

4. Ерасова Л.Г. Глаголы физического восприятия в современном английском и французском языках: Автореф. дис. ... канд. филол. наук. -Воронеж, 1973. - С. 4.

5. Лингвистический энциклопедический словарь. - М., 1990.

6. Степанова Г.В. Семантика многозначного глагола. - Калининград, 1978. - С. 7.

7. Юлдашев А.А. Глаголы чувственного восприятия в тюркских языках // Историческое развитие лексики тюркских языков. - М., 1961. - С. 296.

(с) Саналова Байару Борисовна (sbayaru@mail.ru). 